\title{
Preferred Leadership Styles, Culture, and Government Fiscal Transparency: An International Analysis
}

\author{
Yaw M. Mensah ${ }^{1, *}$, Yanxia $\mathbf{Q i}^{2}$ \\ ${ }^{1}$ Center for Governmental Accounting Education and Research, Rutgers Business School, Rutgers University, USA \\ ${ }^{2}$ Department of Accounting and Finance, School of Business Administration, China University of Petroleum, China
}

Copyright $\mathrm{O} 2016$ by authors, all rights reserved. Authors agree that this article remains permanently open access under the terms of the Creative Commons Attribution License 4.0 International License

\begin{abstract}
Evidence provided by the GLOBE study (House et al [1]) has shown that different cultures have definite preferences for different leadership styles. This study examines whether the cultural preference for specific leadership styles has implications for the development of transparency in government budgetary reporting. Our results show that the Performance-Oriented and the Autonomous leadership styles are positively associated with greater transparency while the Team-Oriented and Humane leadership styles have a negative relationship. When Lewin's classical leadership styles are introduced, we found that both the Democratic and Autocratic leadership styles were positively associated with budget transparency. In contrast, the Delegative leadership style is found to be negatively associated with budget transparency. One major implication of this study is that the movement towards greater transparency in government budgeting would be facilitated by changes in cultural preferences for certain leadership styles.
\end{abstract}

Keywords Budget Transparency, Leadership Styles, GLOBE Leadership Styles, Lewin Leadership Styles

JEL Classification: L38, H61

\section{Introduction}

This study examines the role that the preferred leadership styles of different cultures play in the adoption of government fiscal transparency. There is considerable evidence in the cross-cultural literature that different cultures prefer different leadership styles. There is also evidence of significant differences in government fiscal transparency across countries. Some of these differences can be explained by the political and economic structures, but the potential effect of the preferred leadership styles of the culture of these countries has not been explored to date. To the extent that specific styles of leadership are associated with different levels of fiscal transparency, the achievement of greater fiscal transparency may also depend on a change in the cultural preference for leadership styles, and not solely on political or economic institutions.

Government fiscal transparency has been defined by Kopits and Craig [2] as: "...openness toward the public at large about government structure and functions, fiscal policy intentions, public sector accounts, and projections. It involves ready access to reliable, comprehensive, timely, understandable, and internationally comparable information on government activities so that the electorate and financial markets can accurately assess the government's financial position and the true costs and benefits of government activities, including their present and future economic and social implications" (page 1). In their view, such transparency is an important condition for good governance and fiscal probity.

The importance of government fiscal transparency was highlighted during the Asian financial crises of the 1997 when the creeping fiscal disequilibrium in many of the Asian "tiger economies", the accumulation of public contingent liabilities, and the vulnerable asset-liability structures went undetected by both investors and watchdog multinational agencies (Marcel and Tokman [3], p.36). Surprisingly, almost 15 years later, history is almost repeating itself with the financial crisis involving Greece which threatens to splinter the Eurozone (Manessiotis [4]).

The Code of Good Practices on Fiscal Transparency, which was developed in 1998 and updated in 2007 by the International Monetary Fund (IMF), emphasized four general principles: (1) clarity of roles and responsibilities, (2) open budget processes, (3) public availability of information, and (4) assurances of integrity (IMF, [5]). Drawing from different member countries' experiences, the Organization of Economic Co-operation and Development (OECD) published Best Practices for Budget Transparency in 2002. OECD [6] defines budget transparency as "the full disclosure of all relevant fiscal information in a timely and systematic manner" (p. 7), and outlines the three areas that should be the focus of best practices: (1) a listing of the 
principal budget reports that governments should produce and their general content, (2) a description of specific disclosures which includes both financial and non-financial performance information, and (3) the highlighting of practices for ensuring the quality and integrity of the government budget reports.

Extant research on the hypothesized determinants of budget transparency has generally identified political governance and economic factors. This study seeks to extend the literature by introducing leadership style as another important determinant. Such an extension would provide better insight into the potential ways in which greater government transparency can be achieved.

In the sections which follow, we first discuss the extant literature on the determinants of budget transparency. We then review the cross-cultural literature and focus on the extent to which different cultures have expressed preferences for certain leadership attributes. We then theorize why certain leadership attributes might have a bearing on the observed levels of budget transparency in an international setting. These discussions are then followed by a description of our methodology in Section III, and our empirical findings in Section IV. Our conclusions are presented in the final section.

\section{Literature Review}

\subsection{Determinants of Government Budgeting Transparency}

Much of the extant research done so far on the determinants of budgeting transparency has been based on the framework on fiscal transparency provided by the IMF and the OECD (see, for example, Matheson [7], Reviglio [8], OECD [6], IMF [9]). The major determinants of budgeting transparency identified in the literature to date are (a) debt structure, (b) political competition, and (c) governance structure, and (d) economic development, (e) regional and cultural influences, (f) centralization of the government, and (g) the type of legal system (civil, common, or religious law).

a. Government debt: Benito and Bastida [10] reported that there was no consistent effect on government transparency. However, Alesina and Perotti [11] found countries with high levels of government debt have the least budget transparency.

b. Political factors: Government election turnout has a positive effect on transparency (Benito and Bastida [10]). Political competition has also been reported to be a positive driver of greater transparency (Alt and Lassen [12]). Similar positive relationships between fiscal transparency and economic and political outcomes have been reported by Allen [13], Montesinos [14], de Renzio and Krafchik [15], and the Open Budget Survey (IBP [16]). Alt, Lassen and Rose [17], in a survey focused on fiscal transparency in the American states, found that political competition and power sharing have statistically positive relationship with fiscal transparency.

c. Political structure: Alt and Lassen [12] found the presidential system was significantly positively associated with higher budgeting transparency. Allen [13] and Montesinos [14] also argue that political systems, government structures, social, and economic factors in different countries significantly impact government financial reporting. IBP [16] reported a positive relationship between lack of transparency and the existence of authoritarian or hybrid systems of government.

d. Economic development: The Open Budget Survey (IBP [16] reported a negative relationship between income levels and government transparency. The survey also found a similar negative relationship between transparency and dependence on foreign aid and the sale of hydrocarbons. Grigorescu [18] argued that governments with higher economic development (in terms of GDP per capita) are more likely to adopt laws on access to information (more transparency) because they pay less attention on relatively high costs involved in gathering, processing, and offering information than poorer countries.

e. Regional and Cultural Influences: Bellver and Kaufmann [19], using a self-constructed transparency index for 194 countries that covers both economic / institutional transparency and political transparency, reported no significant relationship between culture or geographical region and their transparency measures. However, they found that greater transparency was associated with higher economic and human development indicators. On the other hand, IBP [16] reported that countries with low transparency scores tended to be located in Africa and the Middle East.

f. Decentralization: The effect of decentralization on budget transparency is mixed. Doig and McIvor [21] argue that fiscal and service decentralization usually weakens democracy, because government activity is less transparent and corruption risk is higher. On the other hand, some other researchers have reported a positive relationship between decentralization and the transparency of budget reports (Shah [22] Arikan [23], Fishman and Gatti [24]). Bouley, Fournel and Leruth [25] also reported that extensive centralization can result in economic distortions and a general lack of accountability and transparency.

g. Legal System: Laws imposing disclosure of governmental information are a powerful tool in enhancing government transparency, decreasing information asymmetry, and closing the power gap between officials and voters (Matheson and Kwon [9]). IMF [9, p.52] argues that fiscal rules and fiscal responsibility (or transparency) laws have been 
implemented as a mechanism to improve fiscal discipline and policy outcomes, and these laws can help to strengthen the credibility of fiscal policies and increase accountability. However, the effectiveness of laws mandating disclosure may also depend on the type of legal regime in place. Originating from the English legal system, common law countries traditionally emphasis the individual property rights and intent to restrict the state (La Porta et al., [26]). Thus, one might expect to find that common law countries have higher levels of budget transparency. Indeed, Alt and Lassen [12] reported evidence from their study that common law has a significantly positive relationship with the budget transparency index.

The current literature show that government budgeting transparency, as a comprehensive indicator of the government budget, may be influenced by a variety of factors, but the influence direction and extent of different factor is mixed. So, it is necessary to further analyze the relevant factors and make a more clear picture.

\subsection{Effects of Government Budgeting Transparency}

While the determinants of government budgeting transparency have not been subject to much research, the effects on the lack of transparency are relatively well-documented. Among these are (a) increased borrowing costs and excessive debt accumulation, (b) positive climate for corruption and decreased public sector governance, (c) reduced fiscal discipline, and (d) decreased economic development.

a. Borrowing costs and debt accumulation: Glennerster and Shin [27] found that higher transparency was associated with decreased borrowing costs. Alt and Lassen [28] found a significantly negative effect of higher transparency on public debt accumulation. Stein, Talvi and Grisanti [29], using data from Latin America, report that more transparent and hierarchical budgetary procedures are associated with lower deficits and debt.

b. Effect on Corruption and Public Sector Governance: Bastida and Benito [30], using the OECD/World Bank Budgeting Database 2003, found that transparency is negatively correlated with corruption. Reinikka and Svensson [31] found the same effect of reduced corruption from greater transparency in Uganda.

c. Fiscal Discipline: Reviglio [8] argues that improvement in budget transparency and expenditure management can decrease information asymmetry and eliminate some budgetary gimmicks that government used to bypass fiscal constraints.

d. Economic Effects: Chortareas, Stasavage, and Sterne [32] found in an international context that greater transparency in publishing forecasts was associated with lower inflation. Tanzi [33] reported that low budget transparency hampers effective expenditure management. Siegle [34] found that transparency has a significant relationship with the evolution of the economic situation of some of the countries he studied. Additional economic effects reported in the literature are more foreign direct investment inflows (Gelos and Wei [35]) and lower sovereign borrowing costs (Glennerster and Shin [27]).

The determinants and the effects of government budgeting transparency have improved that government budgeting transparency has a close relationship with economic, political and cultural environment. However, there is not further research on the relationship between budgeting transparency and leadership style which roots in culture.

\subsection{Culture, Preferred Leadership Styles and Government Budgeting Transparency}

Culture is a representation of the shared values, attitudes, belief and behavior among a group of people (Matsumoto and Juang [36]). Therefore, it is to be expected that national culture greatly influences the thinking and behavior of the people living in the same social environment (Hofstede [37]). The attributes and behaviors of leaders are a reflection of societal cultures, and are differentially expected and viewed in specific culture (Kopelman, Brief and Guzzo [38]). House, Wright and Aditya [39] believe that "what is expected of leaders, what leaders may and may not do, and the influence that leaders have vary considerably as a result of the cultural forces in the countries or regions in which the leaders function" (p.535).

Leadership styles have important impact on political behavior. The particular leadership style that leaders adopt can affect the manner in which they maintain control over policy and shape the policy agenda, and, in turn, the nature of the decision-making process (Hermann [40]). Zaccaro and Klimoski [41 p. 12] also argue that "the hierarchical context of leadership has profound effects on the personal, interpersonal, and organizational choices that can be made." Ammeter et al. [42] also see culture as framing and shaping leadership behaviors.

Leadership style can impact outcomes for individuals and their organization through political behavior. "Culture at various levels of analysis, for example group, unit, organization, country, may mediate political behavior" (Kurchner-Hawkins and Miller [43, p.343]). They further argue that political behavior should be conceived of as a continuum of behaviors that has ends ranging from negative to positive. They further ague that political behavior is multidimensional and contextual, that is they arise in specific problem-solving and decision-making contexts. Consideration of the multidimensional aspects of the determinants of positive political behavior helps to identify blind spots in strategy and makes the potential full range of strategies more transparent (Kurchner-Hawkins and Miller [43]). 
As a potentially important factor in effectiveness of leader's behaviors, leadership style is regarded as the manner in which leaders express particular behaviors, which likely contributes to the target's interpretation of and subsequent effectiveness of such behaviors (Ammeter et al. [42, p.782]). Using two types of leadership style, Lowe, Galen Kroech and Sivasubramaniam [44] confirm that different leadership styles are associated with different effectiveness by finding that there are higher associations between transformational leadership and work unit effectiveness than between transactional scales and effectiveness.

In summary, it is reasonable to conclude that, just like in other areas of human behavior, the extent to which countries exhibit budget transparency will be dependent in part on their cultural preferences for leadership styles. Some leadership styles may prefer openness and candor, while other leadership styles may prefer the restriction of knowledge to a select few associates. For this reason, an examination of the different leadership styles and their likely responsiveness to the sharing of government budgeting information is of interest.

\subsubsection{Leadership Style by GLOBE and Political Behavior}

The Global Leadership and Organizational Behavior Effectiveness Research Program (GLOBE) was a global research undertaking that drew upon investigators from 62 different countries (House, Hanges, Javidan, Dorfman, and Gupta [1]). The researchers first grouped the countries into ten cultural groups: Anglo, Germanic Europe, Nordic Europe, Latin Europe, Eastern Europe, Sub-Saharan Africa, Latin America, Middle Eastern, Confucian Asia, and South-East Asia. By classifying the responses from surveys conducted in each of these cultural clusters and analyzing them, the researchers obtained the following six leadership styles (Hoppe [45]):

1. The performance-oriented style (or "charismatic/value-based" style) stresses high standards, decisiveness, and innovation. The leader seeks to inspire people around a vision and hold on to core values.

2. The team-oriented style instills pride, loyalty, and collaboration among organizational members. The leader values team cohesiveness and sets a common purpose or goals for the team to achieve.

3. The participative style encourages input from others in decision-making and implementation. The leader emphasizes delegation and equality.

4. The humane style stresses compassion and generosity. The leader exhibits patience, is highly supportive, and is concerned with the well-being of others.

5. The autonomous style is characterized by an independent, individualistic, and self-centric approach to leadership.

6. The self-protective (or group-protective) style emphasizes procedural, status-conscious, and "face-saving" behaviors. The leader focuses on the safety and security of the individual and the group.

The mapping of the ten cultural clusters to the six leadership styles in the GLOBE study is presented in Appendix I. Since the order in which the ten clusters are presented in Appendix I is based on the relative importance of that leadership attribute to the culture, numerical scores can be assigned to link the cultural cluster to the leadership style. For example, there are three classifications in the performance-oriented leadership style which reflect the performance-oriented degree in ten cultural clusters. Based on these classification, we use different numerical scores to quantify it (using 1.1 for low performance-oriented culture cluster, using 2.1 to 2.3 for high performance-oriented culture cluster, and using 3.1-3.6 to reflect leadership attribute in the first classification). The specific scheme adopted is identified in Appendix I, based on the statistical significance of the differences within the leadership styles and the rank orders within each sub-set. Using the approach presented in Appendix I, we derived the scores for the leadership styles in Appendix II.

\section{Performance-Oriented Leadership Style (PER_ORT)}

Based on the description of the different leadership styles, we hypothesize that performance oriented leaders are likely to want to achieve results. Performance-oriented leadership pay more attention on performance measurement which can not only measure the outcomes and results of governments but also promote better budgeting transparency. According to Holloway [46], performance-oriented (or task-oriented) leaders rely on one-way communication to provide direction to subordinates. Thus, because of evidence pointing out the positive benefits of greater transparency on economic development, performance-oriented leaders are more likely to achieve the high results they seek if they adopt a higher budget transparency. This leads to our first hypothesis:

H1: The performance-oriented leadership style (PER_ORT) will be positively associated with higher budget transparency.

\section{Team-Oriented Leadership Style (TEAM_OR)}

The team-oriented leader is highly focused on instilling pride and loyalty among team members. Given this focus, it is not evident that sharing budget information, if it is adverse, will necessarily be in this leader's interest. This suggests that what posture a team-oriented leader will adopt towards budget transparency will be situation-specific. If such a leader were leading an economically-successful country, there would be high budget transparency. In contrast, such leaders in economically-challenged countries are likely to avoid high budget transparency. The summary data in Appendix I shows that the team-oriented leadership styles are generally admired in all cultures, but within that overall grouping, the South-Asian and Confucian cultures have a higher preference than the Germanic and Middle-East cultures. Thus, we expect that TEAM_OR will have a negative sign, consistent with the intuition that it is more 
preferred in countries with relatively lower economic performance. However, the sign could change if these societies have better economic news to report. This leads to the second hypothesis:

H2: The team-oriented leadership style (TEAM_OR) will be negatively related to higher budget transparency.

\section{Participative Leadership Style (PARTCP)}

The participative leadership style is characterized by an emphasis on equality and delegation of authority. This leadership style (also called "relations-oriented") relies on two-way communications, and present subordinates with a vision of the common objectives and the means to achieve them (Holloway [46]; Northouse [47]; Yuki [48]). Since it would seem obvious that information has to be shared if such a leadership style is to be effective, we hypothesize a positive relationship between the preference for such a leadership style and the existence of high budget transparency. This is stated formally as Hypothesis H3:

H3: The participative leadership style (PARTCP) will be positively associated with higher budget transparency.

\section{Humane Leadership Style (HUMANE)}

The humane leadership style (HUMANE) is characterized by a high level of patience and sensitivity to the welfare of others. To the extent that transparency and candor increases the general welfare (through reducing the anxieties that lack of information may create), one could hypothesize that a society's preference for the humane leadership style will be associated with higher budget transparency. However, a stronger argument for a negative relationship can be made at the same time. If economic conditions are adverse or expected to be adverse, a truthful revelation could cause severe social anxieties. House et al. [49] describes "face-saving leadership" as leadership with a tendency to avoid embarrassing others, thus leading to the use of ambiguous and indirect language easily subject to misinterpretation. This argument suggests that budget transparency will be lower in societies that prefer humane leadership. This leads to the fourth hypothesis H4:

H4: The humane leadership style (HUMANE) is negatively associated with higher budget transparency.

\section{Autonomous Leadership Style (AUTON)}

The autonomous leadership style is characterized by an independent style that tends to be self-centric. Given such a personality type, it is reasonable to hypothesize that such leaders will tend to discourage information-sharing. More specifically, Javidan, Dorfman, Howell and Hanges [50, p. 350] argue that societies that value performance orientation dislike autonomous leaders because their self-centered approach tends to demotivate other team members. Thus, we hypothesize a negative relationship between the autonomous leadership style and the degree of budget transparency, leading to Hypothesis H5:

H5: The autonomous leadership style (AUTON) is negatively associated with higher budget transparency.

\section{Self-protective/Group-protective Leadership Style (SG_PROT)}

The self- or group-protective leadership style (SG_PROT) is characterized by a herd mentality that seeks to protect the image of the leader or the group, even at the cost of the general welfare. Thus, it is reasonable to expect that such a leadership style may be characterized by a resistance to share information candidly, including budget information, if the data was poor and would reflect poorly on the leader or group. In contrast, if the budget data contains very favorable news, one would expect much greater transparency. This suggests that the extent of budget disclosure may be mixed, with positive information widely disseminated while unfavorable information was withheld.

The SG_PROT leadership style is highly preferred in the Middle East and Confucian/Southeast Asian countries while held in low esteem in the Anglo, Germanic and Nordic countries. This further reinforces the view above that the observed effects of SG_PROT is likely to be mixed. In any case, we do not hypothesize any consistent relationship between SG_PROT and budget transparency, leading to the sixth hypothesis, H6:

H6: The self-protective/group-protective leadership style (SG_PROT) is not systematically associated with higher budget transparency.

\subsubsection{Alternative Leadership Styles}

A different approach to the identification of leadership attributes that is relevant here is the classical leadership styles of Lewin, Lippit and White[51]: (1) Authoritarian Leadership, (2) Participative Leadership, and (3) Delegative (Laissez-Faire) Leadership.

Authoritarian Leadership Style (AUTOC) is defined by leaders who provide clear guidance on their expectations from subordinates, also make decisions independently with little or no input from the rest of the group. Naturally, we expect such leadership style to be associated with low budget transparency, leading to $\mathrm{H} 7$ :

H7: Authoritarian or Autocratic Leadership style (AUTOC) will be negatively related to higher budget transparency.

We adopt as our proxy measure of the Authoritarian Leadership style (denoted as AUTOC) the merger of the AUTON and SG_PROT from the GLOBE study. Both the Autonomous and Self-Protective leadership styles emphasize the interests of the self or group at the expense of the general welfare. There is also little inclination to involve others (outside the group surrounding the leader) in the decision-making process.

Participative Leadership Style (DEMOC) is characterized by leaders who offer guidance to group members, and allow group members to share in the decision-making. Because this leadership style relies on consensus building, information dissemination would seem to be critical. Thus, we expect a high level of budget transparency in societies where such leadership style is 
preferred, leading to the eighth hypothesis:

H8: The Participative or Democratic Leadership style (DEMOC) will be positively associated with higher budget transparency.

Our proxy measure of the Participative/Democratic leadership style (DEMOC) is the combination of PARTCP and PER_ORT from the GLOBE study. The relationship between PARTCP and DEMOC is self-evident. The PER_ORT leadership style belongs to this grouping because charismatic leaders, through ego or self-image, prefer to test their popularity through landslide election wins. Allowing the democratic processes is thus in the interests of the charismatic leader.

The Delegative (Laissez-Faire) Leadership Style (DELEG) is characterized by leaders who offer very limited guidance (if any) to group members. This essentially compels the wider group to serve as the decision-making entity. However, without any guidance from the top, it is not easy to see how a consistent policy of wider dissemination of high quality information will happen. For this reason principally, we expect such a leadership style preference to be associated with a low level of transparency. It is not so much active act of dissimulation as much as poor governance and decentralized decision-making that allows for pockets of good information and total lack of information. This reasoning leads to the ninth hypothesis:

H9: The Delegative (Laissez-Faire) Leadership style (DELEG) will be negatively associated with higher budget transparency.

The DELEG proxy measure is the average of the HUMANE and TEAM_OR from the GLOBE study. The HUMANE group belongs to this grouping because the display of empathy by the leader may often result in delays in decision-making as various objections are resolved through compromises that may not necessarily involve the leader. TEAM_OR belongs also to this set because the leadership style here involves consulting within the group to get consensus. The wider the group, the more likely it is that the leader's direct influence on the final outcome will be diluted.

\section{Results}

\subsection{Data Sources and Sample Selection}

The dependent variable (budget transparency indices) was gathered from the Open Budget Index for 2008, and 2010. In addition, for 2004, we used the economic/financial transparency index compiled by Bellver and Kaufmann [19].

The variables used in this study can be grouped into five categories:
a. Type of Government (PRES, PALA, and OTH_GOVT);

\author{
b. Type of Legal System (COMMON, CIVIL, RELIG); \\ c. Economic factor (GNP_PP) \\ d. Political factors (EFTV, LEGIT, and RUL_LAW); \\ e. Leadership styles (the GLOBE set and the Lewin et al. \\ [51] set).
}

The types of governments identified were gathered from Wikipedia.org and from the individual country websites when necessary. PRES is a dummy variable which referred to countries with executive presidents (with powers separate from the legislature). PALA is a dummy variable which refereed to countries with parliamentary systems where the head of state (president or monarch) plays a mostly ceremonial role. All other countries were labeled as OTH_GOVT, and OTH_GOVT was left out of the equation estimated to avoid perfect collinearity.

The type of law was identified also from Wikipedia.org or from the individual country web sites. COMMON is a dummy variable referring to countries following the English common law system or tradition. CIVIL is a dummy variable referring to countries which follow the civil code. RELIG is a dummy variable which referred to countries which follow the Sharia (or Islamic religious laws). Because some countries had a multiplicity of law types operating simultaneously, all three dummy variables could be included in the regression equations.

The economic variable, GNP_PP (gross national product per person based on purchasing-power parity), was gathered from the IMF statistical database. EFTV is a measure of perceived government effectiveness, LEGIT measured the perceived government legitimacy, and RUL_LAW is the perceived rule-of-law measure for the respective countries. Two of the three political governance variables (EFTV and LEGIT) were gathered from the average scores for the respective years reported from the Polity IV surveys. The third, RUL_LAW (rule of law), was gathered from the World Bank surveys.

The equation estimated can be written generically as:

$$
\begin{gathered}
\text { OBI }_{\mathrm{i}}=\alpha_{11}+\lambda_{1 \mathrm{k}}[\text { Government Type }]_{\mathrm{k}}+\lambda_{2 \mathrm{~L}}[\text { Law Type }]_{\mathrm{L}}+ \\
\lambda_{3} \mathrm{GNP}_{-} \mathrm{PP}_{\mathrm{i}}+\lambda_{4 \mathrm{M}}[\text { Political Factors }]_{\mathrm{M}}+\lambda_{5 \mathrm{~N}}[\text { Leadership } \\
\text { Styles }]_{\mathrm{N}}+\mathrm{e}
\end{gathered}
$$

\subsection{Summary Statistics}

To help in interpreting the results, the list of countries included in the sample is provided in Table 1. Although the list includes 90 countries, not all the countries were included in the analysis for various years because of missing data. Also the original 62 countries included in the GLOBE study have been extended by including all countries for which the geographic location, religion, or language indicate sufficiently close links to the countries included in the original GLOBE study to enable classification. 
Table 1. List of Countries and Scores on Preferred Leadership Styles Classified According to the GLOBE Study

\begin{tabular}{|c|c|c|c|c|c|c|c|c|c|}
\hline Country & $\begin{array}{l}\text { PER- } \\
\text { ORT }\end{array}$ & TEAM-OR & PARTCP & HUMANE & AUTON & SG_PROT & DEMOC & DELEG & AUTOC \\
\hline Afghanistan & 11 & 31 & 11 & 23 & 32 & 35 & 11 & 27 & 33.5 \\
\hline Albania & 21 & 36 & 14 & 21 & 38 & 31 & 17.5 & 28.5 & 34.5 \\
\hline Algeria & 11 & 31 & 11 & 23 & 32 & 35 & 11 & 27 & 33.5 \\
\hline Angola & 22 & 35 & 21 & 32 & 33 & 22 & 21.5 & 33.5 & 27.5 \\
\hline Argentina & 31 & 37 & 22 & 22 & 30 & 32 & 26.5 & 29.5 & 31 \\
\hline Azerbaijan & 33 & 39 & 23 & 34 & 35 & 33 & 28 & 36.5 & 34 \\
\hline Bangladesh & 33 & 39 & 23 & 34 & 35 & 33 & 28 & 36.5 & 34 \\
\hline Bolivia & 31 & 37 & 22 & 22 & 30 & 32 & 26.5 & 29.5 & 31 \\
\hline $\begin{array}{l}\text { Bosnia and } \\
\text { Herzegovina }\end{array}$ & 21 & 36 & 14 & 21 & 38 & 31 & 17.5 & 28.5 & 34.5 \\
\hline Botswana & 22 & 35 & 21 & 32 & 33 & 22 & 21.5 & 33.5 & 27.5 \\
\hline Brazil & 31 & 37 & 22 & 22 & 30 & 32 & 26.5 & 29.5 & 31 \\
\hline Bulgaria & 21 & 36 & 14 & 21 & 38 & 31 & 17.5 & 28.5 & 34.5 \\
\hline Burkina Faso & 22 & 35 & 21 & 32 & 33 & 22 & 21.5 & 33.5 & 27.5 \\
\hline Cambodia & 33 & 39 & 23 & 34 & 35 & 33 & 28 & 36.5 & 34 \\
\hline Cameroon & 22 & 35 & 21 & 32 & 33 & 22 & 21.5 & 33.5 & 27.5 \\
\hline Chad & 22 & 35 & 21 & 32 & 33 & 22 & 21.5 & 33.5 & 27.5 \\
\hline Chile & 31 & 37 & 22 & 22 & 30 & 32 & 26.5 & 29.5 & 31 \\
\hline China & 23 & 38 & 12 & 31 & 37 & 34 & 17.5 & 34.5 & 35.5 \\
\hline Colombia & 31 & 37 & 22 & 22 & 30 & 32 & 26.5 & 29.5 & 31 \\
\hline $\begin{array}{c}\text { Congo, } \\
\text { Democratic }\end{array}$ & 22 & 35 & 21 & 32 & 33 & 22 & 21.5 & 33.5 & 27.5 \\
\hline Costa Rica & 31 & 37 & 22 & 22 & 30 & 32 & 26.5 & 29.5 & 31 \\
\hline Croatia & 21 & 36 & 14 & 21 & 38 & 31 & 17.5 & 28.5 & 34.5 \\
\hline Czech Republic & 21 & 36 & 14 & 21 & 38 & 31 & 17.5 & 28.5 & 34.5 \\
\hline $\begin{array}{l}\text { Dominican } \\
\text { Republic }\end{array}$ & 31 & 37 & 22 & 22 & 30 & 32 & 26.5 & 29.5 & 31 \\
\hline Ecuador & 31 & 37 & 22 & 22 & 30 & 32 & 26.5 & 29.5 & 31 \\
\hline Egypt & 11 & 31 & 11 & 23 & 32 & 35 & 11 & 27 & 33.5 \\
\hline El Salvador & 31 & 37 & 22 & 22 & 30 & 32 & 26.5 & 29.5 & 31 \\
\hline $\begin{array}{c}\text { Equatorial } \\
\text { Guinea }\end{array}$ & 22 & 35 & 21 & 32 & 33 & 22 & 21.5 & 33.5 & 27.5 \\
\hline France & 32 & 34 & 23 & 12 & 31 & 21 & 27.5 & 23 & 26 \\
\hline Georgia & 21 & 36 & 14 & 21 & 38 & 31 & 17.5 & 28.5 & 34.5 \\
\hline Germany & 35 & 30 & 33 & 24 & 37 & 12 & 34 & 27 & 24.5 \\
\hline Ghana & 22 & 35 & 21 & 32 & 33 & 22 & 21.5 & 33.5 & 27.5 \\
\hline Guatemala & 31 & 37 & 22 & 22 & 30 & 32 & 26.5 & 29.5 & 31 \\
\hline Honduras & 31 & 37 & 22 & 22 & 30 & 32 & 26.5 & 29.5 & 31 \\
\hline India & 33 & 39 & 23 & 34 & 35 & 33 & 28 & 36.5 & 34 \\
\hline Indonesia & 33 & 39 & 23 & 34 & 35 & 33 & 28 & 36.5 & 34 \\
\hline Italy & 32 & 34 & 23 & 12 & 31 & 21 & 27.5 & 23 & 26 \\
\hline Jordan & 11 & 31 & 11 & 23 & 32 & 35 & 11 & 27 & 33.5 \\
\hline Kazakhstan & 21 & 36 & 14 & 21 & 38 & 31 & 17.5 & 28.5 & 34.5 \\
\hline Kenya & 22 & 35 & 21 & 32 & 33 & 22 & 21.5 & 33.5 & 27.5 \\
\hline Kyrgyzstan & 21 & 36 & 14 & 21 & 38 & 31 & 17.5 & 28.5 & 34.5 \\
\hline Lebanon & 11 & 31 & 11 & 23 & 32 & 35 & 11 & 27 & 33.5 \\
\hline Liberia & 22 & 35 & 21 & 32 & 33 & 22 & 21.5 & 33.5 & 27.5 \\
\hline Macedonia & 21 & 36 & 14 & 21 & 38 & 31 & 17.5 & 28.5 & 34.5 \\
\hline Malawi & 22 & 35 & 21 & 32 & 33 & 22 & 21.5 & 33.5 & 27.5 \\
\hline Malaysia & 33 & 39 & 23 & 34 & 35 & 33 & 28 & 36.5 & 34 \\
\hline Mali & 22 & 35 & 21 & 32 & 33 & 22 & 21.5 & 33.5 & 27.5 \\
\hline
\end{tabular}




\begin{tabular}{|c|c|c|c|c|c|c|c|c|c|}
\hline Mexico & 31 & 37 & 22 & 22 & 30 & 32 & 26.5 & 29.5 & 31 \\
\hline Mongolia & 23 & 38 & 12 & 31 & 37 & 34 & 17.5 & 34.5 & 35.5 \\
\hline Morocco & 11 & 31 & 11 & 23 & 32 & 35 & 11 & 27 & 33.5 \\
\hline Mozambique & 22 & 35 & 21 & 32 & 33 & 22 & 21.5 & 33.5 & 27.5 \\
\hline Namibia & 22 & 35 & 21 & 32 & 33 & 22 & 21.5 & 33.5 & 27.5 \\
\hline Nepal & 33 & 39 & 23 & 34 & 35 & 33 & 28 & 36.5 & 34 \\
\hline New Zealand & 36 & 32 & 32 & 33 & 34 & 13 & 34 & 32.5 & 23.5 \\
\hline Nicaragua & 31 & 37 & 22 & 22 & 30 & 32 & 26.5 & 29.5 & 31 \\
\hline Niger & 22 & 35 & 21 & 32 & 33 & 22 & 21.5 & 33.5 & 27.5 \\
\hline Nigeria & 22 & 35 & 21 & 32 & 33 & 22 & 21.5 & 33.5 & 27.5 \\
\hline Norway & 34 & 33 & 31 & 11 & 36 & 11 & 32.5 & 22 & 23.5 \\
\hline Pakistan & 11 & 31 & 11 & 23 & 32 & 35 & 11 & 27 & 33.5 \\
\hline Peru & 31 & 37 & 22 & 22 & 30 & 32 & 26.5 & 29.5 & 31 \\
\hline Philippines & 33 & 39 & 23 & 34 & 35 & 33 & 28 & 36.5 & 34 \\
\hline Poland & 21 & 36 & 14 & 21 & 38 & 31 & 17.5 & 28.5 & 34.5 \\
\hline Portugal & 32 & 34 & 23 & 12 & 31 & 21 & 27.5 & 23 & 26 \\
\hline Romania & 21 & 36 & 14 & 21 & 38 & 31 & 17.5 & 28.5 & 34.5 \\
\hline Russia & 21 & 36 & 14 & 21 & 38 & 31 & 17.5 & 28.5 & 34.5 \\
\hline Rwanda & 22 & 35 & 21 & 32 & 33 & 22 & 21.5 & 33.5 & 27.5 \\
\hline Saudi Arabia & 11 & 31 & 11 & 23 & 32 & 35 & 11 & 27 & 33.5 \\
\hline Senegal & 22 & 35 & 21 & 32 & 33 & 22 & 21.5 & 33.5 & 27.5 \\
\hline Serbia & 21 & 36 & 14 & 21 & 38 & 31 & 17.5 & 28.5 & 34.5 \\
\hline Slovak Republic & 21 & 36 & 14 & 21 & 38 & 31 & 17.5 & 28.5 & 34.5 \\
\hline Slovenia & 21 & 36 & 14 & 21 & 38 & 31 & 17.5 & 28.5 & 34.5 \\
\hline South Africa & 29 & 33.5 & 26.5 & 32.5 & 33.5 & 17.5 & 27.75 & 33 & 25.5 \\
\hline South Korea & 23 & 38 & 12 & 31 & 37 & 34 & 17.5 & 34.5 & 35.5 \\
\hline Spain & 32 & 34 & 23 & 12 & 31 & 21 & 27.5 & 23 & 26 \\
\hline Sri Lanka & 33 & 39 & 23 & 34 & 35 & 33 & 28 & 36.5 & 34 \\
\hline Sudan & 22 & 35 & 21 & 32 & 33 & 22 & 21.5 & 33.5 & 27.5 \\
\hline Sweden & 34 & 33 & 31 & 11 & 36 & 11 & 32.5 & 22 & 23.5 \\
\hline Tanzania & 22 & 35 & 21 & 32 & 33 & 22 & 21.5 & 33.5 & 27.5 \\
\hline Thailand & 33 & 39 & 23 & 34 & 35 & 33 & 28 & 36.5 & 34 \\
\hline Timor-leste & 33 & 39 & 23 & 34 & 35 & 33 & 28 & 36.5 & 34 \\
\hline $\begin{array}{c}\text { Trinidad and } \\
\text { Tobago }\end{array}$ & 22 & 35 & 21 & 32 & 33 & 22 & 21.5 & 33.5 & 27.5 \\
\hline Turkey & 11 & 31 & 11 & 23 & 32 & 35 & 11 & 27 & 33.5 \\
\hline Uganda & 22 & 35 & 21 & 32 & 33 & 22 & 21.5 & 33.5 & 27.5 \\
\hline Ukraine & 21 & 36 & 14 & 21 & 38 & 31 & 17.5 & 28.5 & 34.5 \\
\hline $\begin{array}{l}\text { United } \\
\text { Kingdom }\end{array}$ & 36 & 32 & 32 & 33 & 34 & 13 & 34 & 32.5 & 23.5 \\
\hline United States & 36 & 32 & 32 & 33 & 34 & 13 & 34 & 32.5 & 23.5 \\
\hline Venezuela & 31 & 37 & 22 & 22 & 30 & 32 & 26.5 & 29.5 & 31 \\
\hline Vietnam & 33 & 39 & 23 & 34 & 35 & 33 & 28 & 36.5 & 34 \\
\hline Yemen & 11 & 31 & 11 & 23 & 32 & 35 & 11 & 27 & 33.5 \\
\hline Zambia & 22 & 35 & 21 & 32 & 33 & 22 & 21.5 & 33.5 & 27.5 \\
\hline \multicolumn{10}{|c|}{ Explanatory Notes } \\
\hline PER_ORT $=$ & Perfor & . & ed c & l. & GLO & & & & \\
\hline HUMĀANE = & Human & hip st & SLOB & & & & & & \\
\hline PARTCP = & Partici & dersh & om GI & & & & & & \\
\hline TEAM_OR = & Team-c & leaders & from & tudy. & & & & & \\
\hline SG_PROT = & Self/Gr & tective & ip style & & & & & & \\
\hline AUTON = & Autono & adersh & rom GI & & & & & & \\
\hline DEMOC $=$ & Combir & Partic & tyle an & hance & style. & & & & \\
\hline DELEG $=$ & Combir & Hums & and $\mathrm{Te}$ & ted sty & & & & & \\
\hline AUTOC = & & Autor & tyle an & up-p & e style. & & & & \\
\hline
\end{tabular}

Table 2 presents summary statistics on the variables for 2010. Among the GLOBE leadership style variables, TEAM_OR and AUTON has very limited ranges (from 30 to 39), mostly reflecting the fact that the cultural clusters on which the measures are based did not exhibit much cross-section difference. 
Table 2. Summary Statistics of Variables of Interest (YEAR=2010)

\begin{tabular}{|c|c|c|c|c|c|}
\hline Variable & Mean & Std Dev & Minimum & Median & Maximum \\
\hline OBI & 43.456 & 23.759 & 0 & 47.5 & 92 \\
\hline PRES & 0.589 & 0.495 & 0 & 1 & 1 \\
\hline PALA & 0.344 & 0.478 & 0 & 0 & 1 \\
\hline CIVIL & 0.800 & 0.402 & 0 & 1 & 1 \\
\hline COMMON & 0.267 & 0.445 & 0 & 0 & 1 \\
\hline RELIG & 0.156 & 0.364 & 0 & 0 & 1 \\
\hline GNP_PP & 11031.860 & 11153.900 & 329.078 & 7404.24 & 51958.9 \\
\hline EFTV & 4.378 & 3.552 & 0 & 4 & 12 \\
\hline LEGIT & 4.500 & 3.025 & 0 & 4 & 12 \\
\hline RUL_LAW & -0.236 & 0.879 & -1.898 & -0.404 & 1.948 \\
\hline PER_ORT & 25.000 & 7.174 & 11 & 22 & 36 \\
\hline HUMANE & 26.206 & 6.555 & 11 & 23 & 34 \\
\hline PARTCP & 19.650 & 5.487 & 11 & 21 & 33 \\
\hline TEAM_OR & 35.439 & 2.379 & 30 & 36 & 39 \\
\hline SG_PROT & 27.828 & 6.639 & 11 & 31 & 35 \\
\hline AUTON & 33.739 & 2.692 & 30 & 33 & 38 \\
\hline DEMOC & 22.325 & 6.068 & 11 & 21.5 & 34 \\
\hline DELEG & 30.822 & 3.791 & 22 & 29.5 & 36.5 \\
\hline AUTOC & 30.783 & 3.608 & 23.5 & 31 & 35.5 \\
\hline \multicolumn{6}{|c|}{ Explanatory Notes } \\
\hline \multicolumn{6}{|c|}{ OBI $=$ Open Budget Index } \\
\hline \multicolumn{6}{|c|}{ PRES $=$ Dummy variable representing separate Presidential or Monarchical Power independent of Legislative Body } \\
\hline \multicolumn{6}{|c|}{$\begin{array}{l}\text { PALA = Dummy variable representing parliamentary governmental type, representing the } \\
\text { country had a more balanced system with a co-equal legislature and the executive branches. }\end{array}$} \\
\hline \multicolumn{6}{|c|}{ CIVIL $=$ Dummy variable representing civil law style } \\
\hline \multicolumn{6}{|c|}{ COMMON $=$ Dummy variable representing common law style } \\
\hline \multicolumn{6}{|c|}{ RELIG $=$ Dummy variable representing religious law } \\
\hline \multicolumn{6}{|c|}{ GNP_PP $=$ Gross domestic product based on purchasing-power parity (PPP) per capita GDP } \\
\hline \multicolumn{6}{|c|}{$\mathrm{EFTV}=$ Government Effectiveness Perception measure from Polity IV } \\
\hline \multicolumn{6}{|c|}{ LEGIT $=$ Government Legitimacy Perception measure from Polity IV } \\
\hline \multicolumn{6}{|c|}{ RUL_LAW = Rule-of-Law Perception measure from Polity IV } \\
\hline \multicolumn{6}{|c|}{ PER_ORT = Performance-oriented style (called charismatic/value-based by GLOBE) } \\
\hline \multicolumn{6}{|c|}{ HUMANE $=$ Humane leadership style from GLOBE study } \\
\hline \multicolumn{6}{|c|}{ PARTCP = Participative leadership style from GLOBE study } \\
\hline \multicolumn{6}{|c|}{ TEAM_OR = Team-oriented leadership style from GLOBE study. } \\
\hline \multicolumn{6}{|c|}{ SG_PROT = Self / Group-protective leadership style. } \\
\hline \multicolumn{6}{|c|}{ AUTON = Autonomous leadership style from GLOBE study. } \\
\hline \multicolumn{6}{|c|}{ DEMOC $=$ Combination of Participative style and Performance-oriented style } \\
\hline $\mathrm{DELEG}=\mathrm{Comb}$ & Humane style & m-oriented sty & & & \\
\hline $\mathrm{AUTOC}=\mathrm{Comb}$ & utonomous & Self / Group & & & \\
\hline
\end{tabular}

Additional pertinent observations in Table 2 are fact that the range of the Policy IV measures of governance range from zero to 12, while the Rule of Law measure from the World Bank survey was from -1.898 to 1.948. The GNP_PP also varied widely from $\$ 329.078$ to $\$ 51,958.9$ per capita. Among the dummy variables, it is interesting to note that the number of PRES systems dominated the PALA systems (53 versus 31). Among the different types of legal systems, CIVIL outnumbered COMMON and RELIG by (72 versus 24 for COMMON and 14 for RELIG).

\subsection{Results of Analysis for GLOBE Variables}

The results of estimating the regression equation using the Open Budget Index measures for budget transparency and the GLOBE measures for the Leadership styles are presented in Table 3.

Looking at the results in Table 3, PRES is positively related to budget transparency in 2008 and 2010. Similarly, COMMON has a positive and statistically significant coefficient in 2008 and 2010. CIVIL is positively and statistically significant in 2008 but not in 2010. Interestingly, RELIG has a negative coefficient in 2010 (but not statistically significant). 
Table 3. Analysis of Effect of Original Leadership Style variables on OBI Transparency Measure

\begin{tabular}{|c|c|c|c|c|c|c|c|c|c|}
\hline & \multicolumn{2}{|c|}{ Overall Sample } & & \multicolumn{2}{|c|}{2008 Sample } & & \multicolumn{2}{|c|}{2010 Sample } & \\
\hline & Coefficient & t-value & & Coefficient & $\mathrm{t}$-value & & Coefficient & t-value & \\
\hline Intercept & 44.313 & 0.97 & & 79.441 & 1.06 & & 44.050 & 0.75 & \\
\hline YR10 & 2.208 & 1.00 & & & & & & & \\
\hline PRES & 16.456 & 3.18 & $* *$ & 15.771 & 2.2 & * & 16.712 & 2.22 & $*$ \\
\hline PALA & 9.292 & 1.76 & $\&$ & 10.734 & 1.51 & & 8.435 & 1.10 & \\
\hline CIVIL & 8.859 & 1.88 & $\&$ & 13.098 & 2.09 & $*$ & 5.072 & 0.75 & \\
\hline COMMON & 19.882 & 4.15 & $* * *$ & 20.498 & 3.00 & $* * *$ & 19.406 & 2.92 & $* *$ \\
\hline RELIG & 0.055 & 0.01 & & 3.720 & 0.66 & & -2.748 & -0.51 & \\
\hline GNP_PP & 0.000 & -0.12 & & 0.000 & 0.08 & & 0.000 & -0.33 & \\
\hline EFTV & -0.362 & -0.52 & & -0.420 & -0.44 & & -0.154 & -0.16 & \\
\hline LEGIT & -1.074 & -1.24 & & -1.229 & -1.05 & & -0.967 & -0.75 & \\
\hline RUL_LAW & 13.163 & 4.98 & $* * *$ & 12.937 & 3.29 & $* * *$ & 13.791 & 3.91 & $* * *$ \\
\hline PER_ORT & 1.545 & 1.81 & $\&$ & 1.970 & 1.45 & & 1.621 & 1.42 & \\
\hline TEAM_OR & -2.484 & -2.18 & $*$ & -1.860 & -1.17 & & -3.210 & -1.99 & $*$ \\
\hline PARTCP & -0.910 & -0.80 & & -2.001 & -1.10 & & -0.662 & -0.44 & \\
\hline HUMANE & -0.604 & -2.65 & $* *$ & -0.656 & -1.92 & $\&$ & -0.571 & -1.74 & $\&$ \\
\hline AUTON & 1.432 & 2.54 & $*$ & 0.579 & 0.62 & & 1.843 & 2.67 & $* *$ \\
\hline SG_PROT & 0.588 & 1.18 & & -0.124 & -0.16 & & 0.946 & 1.47 & \\
\hline \multicolumn{2}{|c|}{ Adjusted R-squared } & 0.6227 & & & 0.5861 & & & 0.5978 & \\
\hline \multicolumn{2}{|c|}{ Number of observations } & 172 & & & 82 & & & 90 & \\
\hline $\begin{array}{lr} & \& \\
* & =\text { signific } \\
* * & =\text { signific } \\
* * * & =\text { signific }\end{array}$ & $\begin{array}{l}\text { All variables } \\
\text { significant at } \\
\text { t at probabilit } \\
\text { it at probabilit } \\
\text { t at probabilit }\end{array}$ & $\begin{array}{l}\text { explainec } \\
\text { bability o } \\
0.05(2-\mathrm{t} \\
0.01(2-\mathrm{t} \\
0.001(2\end{array}$ & $\begin{array}{l}\text { able } 2 \text {. } \\
\text { (2-ta }\end{array}$ & & & & & & \\
\hline
\end{tabular}

Among the economic and political factors, GNP_PP is not statistically significant in either year (nor in the aggregate), and neither EFTV nor LEGIT are significant either. However, RUL_LAW is positive and statistically significant in both 2008 and 2010.

An examination of the significance of the six leadership styles reveals some surprises. Given below are the original hypotheses, the expected signs, and the observed signs of the coefficients:

\begin{tabular}{|c|c|c|}
\hline Hypothesis & $\begin{array}{c}\text { Expected sign of } \\
\text { coefficient }\end{array}$ & Actual sign of coefficient \\
\hline H1: PER_ORT & Positive & $\begin{array}{c}\text { Positive and significant in } \\
\text { pooled sample only }\end{array}$ \\
\hline $\begin{array}{c}\text { H2: } \\
\text { TEAM_ORT }\end{array}$ & Negative & $\begin{array}{c}\text { Negative relationship in } \\
2010 \text { and overall }\end{array}$ \\
\hline H3: PARTCP & Positive & No relationship \\
\hline H4: HUMANE & Negative & $\begin{array}{c}\text { Negative relationship in } \\
\text { 2008 and 2010 }\end{array}$ \\
\hline H5: AUTON & Negative & $\begin{array}{c}\text { Positive and significant in } \\
2010 \text { and overall }\end{array}$ \\
\hline H6: SG_PROT & $\begin{array}{c}\text { No systematic } \\
\text { relationship }\end{array}$ & No relationship \\
\hline
\end{tabular}

These results are surprising because only PER_ORT, SG_PROT, and AUTON were consistent with prior expectations. PARTCP was expected to be positive but turned out to have no statistically significant relationship. HUMANE was also expected to be positive but turned out the have a negative relationship.
The actual sign of the coefficients for TEAM ORT and HUMANE are negative, and that of AUTON is positive. We also note that since AUTON indicates a top-down decision-making process, the leader can maintain control over policy and the followers accept the leader's supervisory direction. In contrast, TEAM_ORT and HUMANE both emphasize some degree of shared decision-making.

Fiscal transparency does not reflect only the leader's thoughts, but also the degree to which the followers implement the leader's policy. Thus, while the inner circle may have full access to the data internally, its full disclosure to the public is what is at issue. The negative coefficient for the TEAM_ORT thus suggests that such leadership style may emphasize full disclosure of information only within the inner circle but not to the general public. Similarly, the negative coefficient for HUMANE may suggest that information is leaked to the public only on a highly selective basis, resulting in a comparatively lower level of budget transparency under this leadership style.

To provide some perspective on these results, the leadership styles can be related to the countries and cultures where they are favored or disfavored. PER_ORT which has a positive relationship with greater budget transparency is favored in the Anglo, Nordic, and Germanic cultures, and not as well favored in the Middle Eastern culture. In contrast, TEAM_OR which is negatively associated with budget transparency, is favored in Southeast Asian, Confucian, and 
Latin American cultures, and not as highly favored in the Middle Eastern and Confucian cultures. Similarly, the HUMANE leadership style is negatively associated with budget transparency and is favored by SE Asian, Anglo, African, and Confucian cultures, and not favored by the Latin European and Nordic cultures. Interestingly, the Self/Group Protective Leadership style (favored in the Middle Eastern and Confucian cultures but disfavored in the Anglo, Germanic, and Nordic cultures) is not statistically related to the degree of budget transparency. Thus, the explanatory role of leadership styles relative to budget transparency is independent of national culture.

More specifically, while two or more leadership styles may be favored in one culture, cross-sectional differences in the expressed preferences of the different cultures enable the effect of the different leadership styles to be identified. The Team-Oriented and Humane leadership styles are systematically related to lower budget transparency. Evidently, achieving group harmony in a political setting is easier to achieve with less candid disclosures of the finances than more complete disclosures. So cultures which are more comfortable with the Humane and Team-Oriented
Leadership styles are willing to accommodate less complete disclosures of the public finances. This suggests a possibly higher degree of political corruption might be tolerated in such culture since budget transparency is generally seen as the converse of corruption.

\subsection{Results of Analysis for LEWIN Variables}

Table 4 presents the results of the analysis using the LEWIN leadership variables (as proxied by combinations of the GLOBE variables).

In Table 4 , six of the nine control variables are statistically significant in the pooled sample. These are PRES, PALA, CIVIL, COMMON, LEGIT, and RUL_LAW. However, RELIG, GNP_PP, and EFTV are not significant. In the individual year samples, only PRES, COMMON, and RUL_LAW are consistently significant with positive coefficients. Among the leadership style variables, AUTOC and DELEG are consistently significant in both the individual year samples and the pooled sample. DEMOC is significant only in the 2010 sample and in the pooled sample, although in the 2008 sample, it is also significant at the 0.10 level in a one-tailed test.

Table 4. Analysis of Effect of Reformulated Leadership Style Variables on OBI Transparency Measure

\begin{tabular}{|c|c|c|c|c|c|c|c|c|c|}
\hline & \multicolumn{2}{|c|}{ Overall Sample } & & \multicolumn{2}{|c|}{2008 Sample } & & \multicolumn{2}{|c|}{2010 Sample } & \\
\hline & Coefficient & $\mathrm{t}$-value & & Coefficient & t-value & & Coefficient & t-value & \\
\hline Intercept & -3.966 & -0.2 & & 6.866 & 0.23 & & -7.742 & -0.30 & \\
\hline YR10 & 2.217 & 1.00 & & & & & & & \\
\hline PRES & 16.351 & 3.35 & $* * *$ & 17.251 & 2.61 & $* *$ & 15.596 & 2.19 & $*$ \\
\hline PALA & 9.504 & 1.91 & $\&$ & 10.917 & 1.63 & & 8.208 & 1.14 & \\
\hline CIVIL & 8.828 & 1.82 & $\&$ & 12.278 & 1.88 & $\&$ & 5.330 & 0.77 & \\
\hline COMMON & 19.780 & 4.18 & $* * *$ & 19.475 & 2.90 & $* *$ & 19.884 & 2.99 & $* *$ \\
\hline RELIG & -0.385 & -0.10 & & 1.412 & 0.25 & & -2.017 & -0.39 & \\
\hline GNP_PP & 0.000 & 0.85 & & 0.000 & 0.49 & & 0.000 & 0.63 & \\
\hline EFTV & 0.069 & 0.11 & & -0.272 & -0.29 & & 0.430 & 0.50 & \\
\hline LEGIT & -1.455 & -1.80 & $\&$ & -1.606 & -1.47 & & -1.419 & -1.19 & \\
\hline RUL_LAW & 13.860 & 5.53 & $* * *$ & 13.518 & 3.70 & $* * *$ & 14.309 & 4.19 & $* * *$ \\
\hline AUTOC & 1.894 & 3.53 & $* * *$ & 1.523 & 1.88 & $\&$ & 2.191 & 3.10 & $* *$ \\
\hline DEMOC & 0.726 & 2.78 & $* *$ & 0.640 & 1.60 & & 0.813 & 2.41 & $*$ \\
\hline DELEG & -1.515 & -3.32 & $* * *$ & -1.484 & -2.09 & $*$ & -1.604 & -2.77 & $* *$ \\
\hline \multicolumn{2}{|c|}{ Adjusted R-squared } & 0.624 & & & 0.5968 & & & 0.6039 & \\
\hline \multicolumn{2}{|c|}{ Number of observations } & 172 & & & 82.00 & & & 90 & \\
\hline
\end{tabular}

All variables are explained in Table 2 .

$\&=$ significant at probability of 0.10 (2-tailed).

* = significant at probability of 0.05 (2-tailed).

** = significant at probability of 0.01 (2-tailed).

$* * *=$ significant at probability of 0.001 (2-tailed). 
An analysis of the detailed results in Table 4 shows the following:

\begin{tabular}{|c|c|c|}
\hline Hypothesis & $\begin{array}{c}\text { Expected sign of } \\
\text { coefficient }\end{array}$ & $\begin{array}{c}\text { Actual sign of } \\
\text { coefficient }\end{array}$ \\
\hline H7: AUTOC & Negative & Positive \\
\hline H8: DEMOC & Positive & Positive \\
\hline H9: DELEG & Negative & Negative \\
\hline
\end{tabular}

The results here are somewhat more consistent with expectations. The DEMOC leadership style is positively related to transparency, as expected, while the DELEG style is negatively associated with transparency, also as expected. The surprise is the findings that the AUTOC style was also positively associated with transparency, instead of the negative relationship expected. This unexpected result may stem from the fact that an autocratic leader may feel fairly secure in power, and thus may see the release of budget information to the public (particularly it is good or manipulated to look good) as helping to secure that power base.

\section{Conclusions}

The results of our analysis of the relationship between preferred leadership style and budget transparency confirmed our prior expectations in some areas but not in other areas. Focusing first on the GLOBE measures, we found the Performance-oriented leadership style to be positively associated with high budget transparency, while the Team-oriented and Humane leadership styles have the opposite effect on transparency. Finally, in accordance with our expectations, we also found the Self/Group-Protective leadership style not to have any consistent relationship with budget transparency.

The findings that were contrary to our expectations include the lack of any statistically significant relationship between the Participative leadership and budgeting transparency, instead of the positive relationship expected. Furthermore, the Autonomous leadership style was found to have a positive relationship with transparency, contrary to the negative relationship expected.

After regrouping the GLOBE leadership measures to align with the three classical leadership styles identified by Lewin et al. [47], we found two of the measures had the expected relationships with budgeting transparency. The Democratic leadership style was positively associated with budgeting transparency, while the Delegative leadership style was negatively related to budgeting transparency. The major unexpected result is that the Autocratic leadership style was positively related to transparency, contrary to the negative relationship expected.

These results suggest that additional research into the leadership traits that are related to particular undesirable behaviors in the public policy arena may yield insight into ways in which political reforms can be achieved. To the extent that national culture is closely linked to preferred leadership styles, and these styles are, in turn, associated with particular undesirable behavior, the attempt to reform that behavior would benefit for an understanding of these linkages.

\section{Appendix I}

Societal Clusters and Leader Styles from GLOBE Study (House et al, 2004) and Scoring System Used in the Study

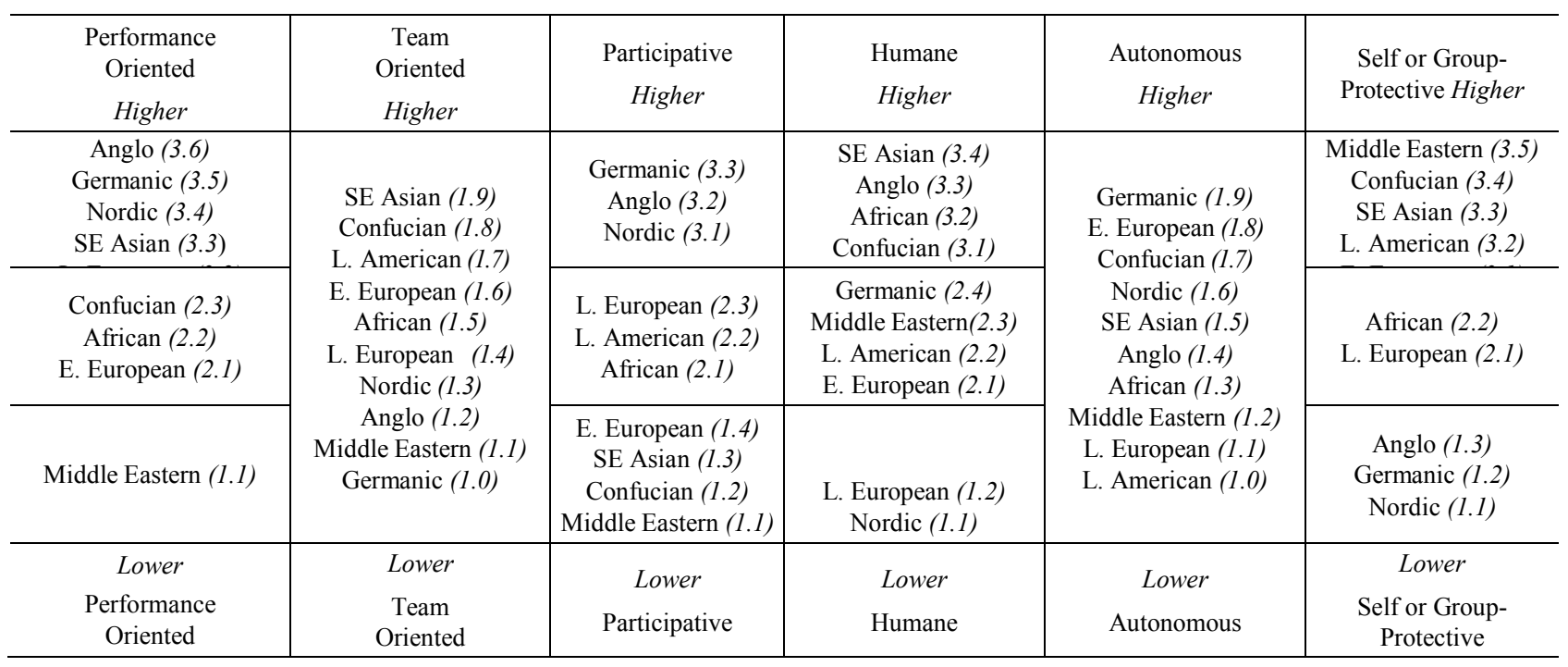

Source: Adapted from House et al., 2004.

(Table copied from http://www.inspireimagineinnovate.com/PDF/GLOBEsummary-by-Michael-H-Hoppe.pdf )

NOTE: The numbers assigned identify the relative weighting scheme applied to the data by the authors to derive the numerical weights used in the empirical analysis. 


\section{Appendix II}

Open Budget Index, the leadership styles and cultural clusters scores in the sample countries in 2010

\begin{tabular}{|c|c|c|c|c|c|c|c|c|c|c|c|c|c|c|c|c|c|}
\hline Country & OBI & CONFUC & ANGLO & GERMAN & $\begin{array}{l}\mathrm{LAT}_{-} \\
\mathrm{AME}\end{array}$ & $\begin{array}{l}\mathrm{LAT}_{-} \\
\text {EUR }\end{array}$ & AFRIC & $\begin{array}{l}\text { EST }_{-} \\
\text {EUR }\end{array}$ & $\begin{array}{c}\text { SE- } \\
\text { ASIA } \\
\end{array}$ & $\begin{array}{l}\text { MID }_{-} \\
\text {EAST }\end{array}$ & NORDIC & $\begin{array}{l}\text { PER- } \\
\text { ORT }\end{array}$ & $\begin{array}{c}\text { TEAM- } \\
\text { OR } \\
\end{array}$ & PARTCP & HUMANE & AUTON & $\begin{array}{c}\mathrm{SG}_{-} \\
\text {PROT }\end{array}$ \\
\hline Afghanistan & 21 & 0 & 0 & 0 & 0 & 0 & 0 & 0 & 0 & 1 & 0 & 11 & 31 & 11 & 23 & 32 & 35 \\
\hline Albania & 33 & 0 & 0 & 0 & 0 & 0 & 0 & 1 & 0 & 0 & 0 & 21 & 36 & 14 & 21 & 38 & 31 \\
\hline Algeria & 1 & 0 & 0 & 0 & 0 & 0 & 0 & 0 & 0 & 1 & 0 & 11 & 31 & 11 & 23 & 32 & 35 \\
\hline Angola & 26 & 0 & 0 & 0 & 0 & 0 & 1 & 0 & 0 & 0 & 0 & 22 & 35 & 21 & 32 & 33 & 22 \\
\hline Argentina & 56 & 0 & 0 & 0 & 1 & 0 & 0 & 0 & 0 & 0 & 0 & 31 & 37 & 22 & 22 & 30 & 32 \\
\hline Azerbaijan & 43 & 0 & 0 & 0 & 0 & 0 & 0 & 0 & 1 & 0 & 0 & 33 & 39 & 23 & 34 & 35 & 33 \\
\hline Bangladesh & 48 & 0 & 0 & 0 & 0 & 0 & 0 & 0 & 1 & 0 & 0 & 33 & 39 & 23 & 34 & 35 & 33 \\
\hline Bolivia & 13 & 0 & 0 & 0 & 1 & 0 & 0 & 0 & 0 & 0 & 0 & 31 & 37 & 22 & 22 & 30 & 32 \\
\hline $\begin{array}{l}\text { Bosnia and } \\
\text { Herzegovina }\end{array}$ & 44 & 0 & 0 & 0 & 0 & 0 & 0 & 1 & 0 & 0 & 0 & 21 & 36 & 14 & 21 & 38 & 31 \\
\hline Botswana & 51 & 0 & 0 & 0 & 0 & 0 & 1 & 0 & 0 & 0 & 0 & 22 & 35 & 21 & 32 & 33 & 22 \\
\hline Brazil & 71 & 0 & 0 & 0 & 1 & 0 & 0 & 0 & 0 & 0 & 0 & 31 & 37 & 22 & 22 & 30 & 32 \\
\hline Bulgaria & 56 & 0 & 0 & 0 & 0 & 0 & 0 & 1 & 0 & 0 & 0 & 21 & 36 & 14 & 21 & 38 & 31 \\
\hline Burkina Faso & 5 & 0 & 0 & 0 & 0 & 0 & 1 & 0 & 0 & 0 & 0 & 22 & 35 & 21 & 32 & 33 & 22 \\
\hline Cambodia & 15 & 0 & 0 & 0 & 0 & 0 & 0 & 0 & 1 & 0 & 0 & 33 & 39 & 23 & 34 & 35 & 33 \\
\hline Cameroon & 2 & 0 & 0 & 0 & 0 & 0 & 1 & 0 & 0 & 0 & 0 & 22 & 35 & 21 & 32 & 33 & 22 \\
\hline Chad & 0 & 0 & 0 & 0 & 0 & 0 & 1 & 0 & 0 & 0 & 0 & 22 & 35 & 21 & 32 & 33 & 22 \\
\hline Chile & 72 & 0 & 0 & 0 & 1 & 0 & 0 & 0 & 0 & 0 & 0 & 31 & 37 & 22 & 22 & 30 & 32 \\
\hline China & 13 & 1 & 0 & 0 & 0 & 0 & 0 & 0 & 0 & 0 & 0 & 23 & 38 & 12 & 31 & 37 & 34 \\
\hline Colombia & 61 & 0 & 0 & 0 & 1 & 0 & 0 & 0 & 0 & 0 & 0 & 31 & 37 & 22 & 22 & 30 & 32 \\
\hline $\begin{array}{c}\text { Congo, } \\
\text { Democratic } \\
\text { Rep. }\end{array}$ & 6 & 0 & 0 & 0 & 0 & 0 & 1 & 0 & 0 & 0 & 0 & 22 & 35 & 21 & 32 & 33 & 22 \\
\hline Costa Rica & 47 & 0 & 0 & 0 & 1 & 0 & 0 & 0 & 0 & 0 & 0 & 31 & 37 & 22 & 22 & 30 & 32 \\
\hline Croatia & 57 & 0 & 0 & 0 & 0 & 0 & 0 & 1 & 0 & 0 & 0 & 21 & 36 & 14 & 21 & 38 & 31 \\
\hline $\begin{array}{l}\text { Czech } \\
\text { Republic }\end{array}$ & 62 & 0 & 0 & 0 & 0 & 0 & 0 & 1 & 0 & 0 & 0 & 21 & 36 & 14 & 21 & 38 & 31 \\
\hline $\begin{array}{c}\text { Dominican } \\
\text { Republic }\end{array}$ & 14 & 0 & 0 & 0 & 1 & 0 & 0 & 0 & 0 & 0 & 0 & 31 & 37 & 22 & 22 & 30 & 32 \\
\hline
\end{tabular}




\begin{tabular}{|c|c|c|c|c|c|c|c|c|c|c|c|c|c|c|c|c|}
\hline Ecuador & 31 & 0 & 0 & 0 & 1 & 0 & 0 & 0 & 0 & 0 & 0 & 31 & 37 & 22 & 22 & 30 \\
\hline Egypt & 49 & 0 & 0 & 0 & 0 & 0 & 0 & 0 & 0 & 1 & 0 & 11 & 31 & 11 & 23 & 32 \\
\hline El Salvador & 37 & 0 & 0 & 0 & 1 & 0 & 0 & 0 & 0 & 0 & 0 & 31 & 37 & 22 & 22 & 30 \\
\hline $\begin{array}{c}\text { Equatorial } \\
\text { Guinea }\end{array}$ & 0 & 0 & 0 & 0 & 0 & 0 & 1 & 0 & 0 & 0 & 0 & 22 & 35 & 21 & 32 & 33 \\
\hline France & 87 & 0 & 0 & 0 & 0 & 1 & 0 & 0 & 0 & 0 & 0 & 32 & 34 & 23 & 12 & 31 \\
\hline Georgia & 55 & 0 & 0 & 0 & 0 & 0 & 0 & 1 & 0 & 0 & 0 & 21 & 36 & 14 & 21 & 38 \\
\hline Germany & 68 & 0 & 0 & 1 & 0 & 0 & 0 & 0 & 0 & 0 & 0 & 35 & 30 & 33 & 24 & 37 \\
\hline Ghana & 54 & 0 & 0 & 0 & 0 & 0 & 1 & 0 & 0 & 0 & 0 & 22 & 35 & 21 & 32 & 33 \\
\hline Guatemala & 50 & 0 & 0 & 0 & 1 & 0 & 0 & 0 & 0 & 0 & 0 & 31 & 37 & 22 & 22 & 30 \\
\hline Honduras & 11 & 0 & 0 & 0 & 1 & 0 & 0 & 0 & 0 & 0 & 0 & 31 & 37 & 22 & 22 & 30 \\
\hline India & 67 & 0 & 0 & 0 & 0 & 0 & 0 & 0 & 1 & 0 & 0 & 33 & 39 & 23 & 34 & 35 \\
\hline Indonesia & 51 & 0 & 0 & 0 & 0 & 0 & 0 & 0 & 1 & 0 & 0 & 33 & 39 & 23 & 34 & 35 \\
\hline Italy & 58 & 0 & 0 & 0 & 0 & 1 & 0 & 0 & 0 & 0 & 0 & 32 & 34 & 23 & 12 & 31 \\
\hline Jordan & 50 & 0 & 0 & 0 & 0 & 0 & 0 & 0 & 0 & 1 & 0 & 11 & 31 & 11 & 23 & 32 \\
\hline Kazakhstan & 38 & 0 & 0 & 0 & 0 & 0 & 0 & 1 & 0 & 0 & 0 & 21 & 36 & 14 & 21 & 38 \\
\hline Kenya & 49 & 0 & 0 & 0 & 0 & 0 & 1 & 0 & 0 & 0 & 0 & 22 & 35 & 21 & 32 & 33 \\
\hline Kyrgyzstan & 15 & 0 & 0 & 0 & 0 & 0 & 0 & 1 & 0 & 0 & 0 & 21 & 36 & 14 & 21 & 38 \\
\hline Lebanon & 32 & 0 & 0 & 0 & 0 & 0 & 0 & 0 & 0 & 1 & 0 & 11 & 31 & 11 & 23 & 32 \\
\hline Liberia & 40 & 0 & 0 & 0 & 0 & 0 & 1 & 0 & 0 & 0 & 0 & 22 & 35 & 21 & 32 & 33 \\
\hline Macedonia & 49 & 0 & 0 & 0 & 0 & 0 & 0 & 1 & 0 & 0 & 0 & 21 & 36 & 14 & 21 & 38 \\
\hline Malawi & 47 & 0 & 0 & 0 & 0 & 0 & 1 & 0 & 0 & 0 & 0 & 22 & 35 & 21 & 32 & 33 \\
\hline Malaysia & 39 & 0 & 0 & 0 & 0 & 0 & 0 & 0 & 1 & 0 & 0 & 33 & 39 & 23 & 34 & 35 \\
\hline Mali & 35 & 0 & 0 & 0 & 0 & 0 & 1 & 0 & 0 & 0 & 0 & 22 & 35 & 21 & 32 & 33 \\
\hline Mexico & 52 & 0 & 0 & 0 & 1 & 0 & 0 & 0 & 0 & 0 & 0 & 31 & 37 & 22 & 22 & 30 \\
\hline Mongolia & 60 & 1 & 0 & 0 & 0 & 0 & 0 & 0 & 0 & 0 & 0 & 23 & 38 & 12 & 31 & 37 \\
\hline Morocco & 28 & 0 & 0 & 0 & 0 & 0 & 0 & 0 & 0 & 1 & 0 & 11 & 31 & 11 & 23 & 32 \\
\hline Mozambique & 28 & 0 & 0 & 0 & 0 & 0 & 1 & 0 & 0 & 0 & 0 & 22 & 35 & 21 & 32 & 33 \\
\hline Namibia & 53 & 0 & 0 & 0 & 0 & 0 & 1 & 0 & 0 & 0 & 0 & 22 & 35 & 21 & 32 & 33 \\
\hline Nepal & 45 & 0 & 0 & 0 & 0 & 0 & 0 & 0 & 1 & 0 & 0 & 33 & 39 & 23 & 34 & 35 \\
\hline New Zealand & 90 & 0 & 1 & 0 & 0 & 0 & 0 & 0 & 0 & 0 & 0 & 36 & 32 & 32 & 33 & 34 \\
\hline Nicaragua & 37 & 0 & 0 & 0 & 1 & 0 & 0 & 0 & 0 & 0 & 0 & 31 & 37 & 22 & 22 & 30 \\
\hline
\end{tabular}




\begin{tabular}{|c|c|c|c|c|c|c|c|c|c|c|c|c|c|c|c|c|c|}
\hline Niger & 3 & 0 & 0 & 0 & 0 & 0 & 1 & 0 & 0 & 0 & 0 & 22 & 35 & 21 & 32 & 33 & 22 \\
\hline Nigeria & 18 & 0 & 0 & 0 & 0 & 0 & 1 & 0 & 0 & 0 & 0 & 22 & 35 & 21 & 32 & 33 & 22 \\
\hline Norway & 83 & 0 & 0 & 0 & 0 & 0 & 0 & 0 & 0 & 0 & 1 & 34 & 33 & 31 & 11 & 36 & 11 \\
\hline Pakistan & 38 & 0 & 0 & 0 & 0 & 0 & 0 & 0 & 0 & 1 & 0 & 11 & 31 & 11 & 23 & 32 & 35 \\
\hline Peru & 65 & 0 & 0 & 0 & 1 & 0 & 0 & 0 & 0 & 0 & 0 & 31 & 37 & 22 & 22 & 30 & 32 \\
\hline Philippines & 55 & 0 & 0 & 0 & 0 & 0 & 0 & 0 & 1 & 0 & 0 & 33 & 39 & 23 & 34 & 35 & 33 \\
\hline Poland & 64 & 0 & 0 & 0 & 0 & 0 & 0 & 1 & 0 & 0 & 0 & 21 & 36 & 14 & 21 & 38 & 31 \\
\hline Portugal & 58 & 0 & 0 & 0 & 0 & 1 & 0 & 0 & 0 & 0 & 0 & 32 & 34 & 23 & 12 & 31 & 21 \\
\hline Romania & 59 & 0 & 0 & 0 & 0 & 0 & 0 & 1 & 0 & 0 & 0 & 21 & 36 & 14 & 21 & 38 & 31 \\
\hline Russia & 60 & 0 & 0 & 0 & 0 & 0 & 0 & 1 & 0 & 0 & 0 & 21 & 36 & 14 & 21 & 38 & 31 \\
\hline Rwanda & 11 & 0 & 0 & 0 & 0 & 0 & 1 & 0 & 0 & 0 & 0 & 22 & 35 & 21 & 32 & 33 & 22 \\
\hline Saudi Arabia & 1 & 0 & 0 & 0 & 0 & 0 & 0 & 0 & 0 & 1 & 0 & 11 & 31 & 11 & 23 & 32 & 35 \\
\hline Senegal & 3 & 0 & 0 & 0 & 0 & 0 & 1 & 0 & 0 & 0 & 0 & 22 & 35 & 21 & 32 & 33 & 22 \\
\hline Serbia & 54 & 0 & 0 & 0 & 0 & 0 & 0 & 1 & 0 & 0 & 0 & 21 & 36 & 14 & 21 & 38 & 31 \\
\hline $\begin{array}{c}\text { Slovak } \\
\text { Republic }\end{array}$ & 57 & 0 & 0 & 0 & 0 & 0 & 0 & 1 & 0 & 0 & 0 & 21 & 36 & 14 & 21 & 38 & 31 \\
\hline Slovenia & 70 & 0 & 0 & 0 & 0 & 0 & 0 & 1 & 0 & 0 & 0 & 21 & 36 & 14 & 21 & 38 & 31 \\
\hline South Africa & 92 & 0 & 1 & 0 & 0 & 0 & 1 & 0 & 0 & 0 & 0 & 29 & 33.5 & 26.5 & 32.5 & 33.5 & 17.5 \\
\hline South Korea & 71 & 1 & 0 & 0 & 0 & 0 & 0 & 0 & 0 & 0 & 0 & 23 & 38 & 12 & 31 & 37 & 34 \\
\hline Spain & 63 & 0 & 0 & 0 & 0 & 1 & 0 & 0 & 0 & 0 & 0 & 32 & 34 & 23 & 12 & 31 & 21 \\
\hline Sri Lanka & 67 & 0 & 0 & 0 & 0 & 0 & 0 & 0 & 1 & 0 & 0 & 33 & 39 & 23 & 34 & 35 & 33 \\
\hline Sudan & 8 & 0 & 0 & 0 & 0 & 0 & 1 & 0 & 0 & 0 & 0 & 22 & 35 & 21 & 32 & 33 & 22 \\
\hline Sweden & 83 & 0 & 0 & 0 & 0 & 0 & 0 & 0 & 0 & 0 & 1 & 34 & 33 & 31 & 11 & 36 & 11 \\
\hline Tanzania & 45 & 0 & 0 & 0 & 0 & 0 & 1 & 0 & 0 & 0 & 0 & 22 & 35 & 21 & 32 & 33 & 22 \\
\hline Thailand & 42 & 0 & 0 & 0 & 0 & 0 & 0 & 0 & 1 & 0 & 0 & 33 & 39 & 23 & 34 & 35 & 33 \\
\hline Timor-leste & 34 & 0 & 0 & 0 & 0 & 0 & 0 & 0 & 1 & 0 & 0 & 33 & 39 & 23 & 34 & 35 & 33 \\
\hline $\begin{array}{l}\text { Trinidad and } \\
\text { Tobago }\end{array}$ & 33 & 0 & 0 & 0 & 0 & 0 & 1 & 0 & 0 & 0 & 0 & 22 & 35 & 21 & 32 & 33 & 22 \\
\hline Turkey & 57 & 0 & 0 & 0 & 0 & 0 & 0 & 0 & 0 & 1 & 0 & 11 & 31 & 11 & 23 & 32 & 35 \\
\hline Uganda & 55 & 0 & 0 & 0 & 0 & 0 & 1 & 0 & 0 & 0 & 0 & 22 & 35 & 21 & 32 & 33 & 22 \\
\hline Ukraine & 62 & 0 & 0 & 0 & 0 & 0 & 0 & 1 & 0 & 0 & 0 & 21 & 36 & 14 & 21 & 38 & 31 \\
\hline $\begin{array}{l}\text { United } \\
\text { Kingdom }\end{array}$ & 87 & 0 & 1 & 0 & 0 & 0 & 0 & 0 & 0 & 0 & 0 & 36 & 32 & 32 & 33 & 34 & 13 \\
\hline
\end{tabular}




\begin{tabular}{|c|c|c|c|c|c|c|c|c|c|c|c|c|c|c|c|c|c|}
\hline United States & 82 & 0 & 1 & 0 & 0 & 0 & 0 & 0 & 0 & 0 & 0 & 36 & 32 & 32 & 33 & 34 & 13 \\
\hline Venezuela & 34 & 0 & 0 & 0 & 1 & 0 & 0 & 0 & 0 & 0 & 0 & 31 & 37 & 22 & 22 & 30 & 32 \\
\hline Vietnam & 14 & 0 & 0 & 0 & 0 & 0 & 0 & 0 & 1 & 0 & 0 & 33 & 39 & 23 & 34 & 35 & 33 \\
\hline
\end{tabular}

Explanatory

Notes

$\mathrm{OBI}=$ Open Budget Index

CONFU $=$ Confucian countries, including Singapore, Hong Kong, Taiwan, China. South Korea, and Japan

ANGLO = Anglo countries, including Canada, U.S.A., Australia, Ireland, England, South Africa, New Zealand

GERMAN = Germanic countries, including Austria, The Netherlands, Switzerland (German Speaking), Germany.

LAT_AME = Latin American, including Ecuador, EL Salvador, Columbia, Bolivia, Brazil, Guatemala, Argentina, Costa Rica, Venezuela, Mexico.

LAT_EUR = Latin European, including Israel, Italy, Switzerland (French Speaking), Spain, Portugal, France.

AFRIC $=$ African countries, including Zimbabwe, Namibia, Zambia, Nigeria, South Africa.

EST_EUR = Eastern European, including Greece, Hungary, Albania, Slovenia, Poland, Russia, Georgia, Kazakhstan.

SE-ASIA = Southeast Asia, including Philippines, Indonesia, Malaysia, India, Thailand, Iran.

MID_EAST $=$ Middle Eastern, including Turkey, Kuwait, Egypt, Morocco, Qatar.

NORDIC $=$ Nordic countries, including Denmark, Finland, Sweden.

PER_ORT $=$ Performance-oriented style (called charismatic/value-based by GLOBE)

HUMANE $=$ Humane leadership style from GLOBE study

PARTCP $=$ Participative leadership style from GLBE study

TEAM_OR $=$ Team-oriented leadership style from GLOBE study.

SG_PROT $=$ Self/Group-Protective leadership style.

AUTON $=$ Autonomous leadership style from GLOBE study . 


\section{REFERENCES}

[1] House, RJ, Hanges PJ, Javidan M, Dorfman PW, Gupta V, editors. Culture, Leadership, and Organizations: The GLOBE Study of 62 Societies. Thousand Oaks, CA: Sage Publications Inc.; 2004

[2] Kopits G, Craig J. Transparency in Government Operations, International Monetary Fund: Washington D.C.; 1998.

[3] Marcel M, Tokman M. Building a consensus for fiscal reform: The Chilean case. OECD Journal of Budgeting. 2002 2(3), p. 35-55.

[4] Manessiotis B. The root-causes of the Greek sovereign debt crisis. Paper presented at the $2^{\text {nd }}$ Bank of Greece Workshop on The Economies of Eastern Europe and Mediterranean Countries, Athens, Greece (May); 2011

[5] International Monetary Fund (IMF). Code of Good Practices on Fiscal Transparency. Washington. D. C: IMF; 2007.

[6] Organization for Economic Cooperation and Development (OECD). OECD Best Practices for Budget Transparency. OECD: Paris, France; 2002.

[7] Matheson A. Better public sector governance: The rationale for budgeting and accounting reform in Western nations. OECD Journal on Budgeting; 2001, 2(1); p. 37-46.

[8] Reviglio F. Budget transparency for public expenditure control. Working Paper No.01/8. Washington DC: International Monetary Fund; 2001.

[9] International Monetary Fund (IMF). Manual for Fiscal Transparency. Washington. D. C: IMF; 2007.

[10] Benito B, Bastida F. Budget transparency, fiscal performance, and political turnout: An international approach. Public Administration Review: 2009, 69(3); p. 403-417.

[11] Alesina AF, Perotti R. Budget deficits and budget institutions. In Poterba JM, von Hagen J, editors. Fiscal Institutions and Fiscal Performance (pp.13-36). University of Chicago Press; 1999.

[12] Alt JE, Lassen DD. The political budget cycle is where you can't see it: Transparency and fiscal manipulation. Economic Policy Research Unit (EPRU) Working Paper Series. University of Copenhagen. Denmark; 2005.

[13] Allen TL. Public accountability and government financial reporting. OECD Journal on Budgeting; 2001, 2(1); p. 11-36.

[14] Montesinos V. Government budget and accounting reforms in Spain. OECD Journal on Budgeting; 2001, 2(1); p. 333-354.

[15] De Renzio, P. Krafchik W. Lessons from the field: The impact of civil society budget analysis and advocacy in six countries. Washington DC: International Budget Project. 2007 [cited February 26, 2012]. Available from: http://www.internationa lbudget.org.

[16] International Budget Partnership (IBP). The Open Budget Survey in 2010, International Budget Partnership: Washington, D.C; 2010.

[17] Alt JE, Lassen DD, Rose S. The causes of fiscal transparency:
Evidence from the American states. Economic Policy Research Unit (EPRU) Working Paper Series. University of Copenhagen. Denmark; 2006.

[18] Grigorescu, A. International organizations and government transparency: Linking the international and domestic realms. International Studies Quarterly. 2003, 47(4); p. 643-667.

[19] Bellver A, Kaufmann D. Transparenting transparency: Initial empirics and policy applications. Policy Research Working Paper. Washington DC: World Bank; 2005.

[20] Doig A. McIvor S. The national integrity system: Assessing corruption and reforms. Public Administration and Development; 2003, 23 (4); p. 317-332.

[21] Shah A. Balance, accountability, and responsiveness: Lessons about decentralization. Policy Research Working Paper Series 2021. Washington, DC: World Bank; 1999.

[22] Arikan GG. Fiscal decentralization: A remedy for corruption? International Tax and Public Finance. 2004. 11(2); p.175-195.

[23] Fishman R, Gatti, R. Decentralization and corruption: Evidence across countries. Journal of Public Economics. 2002, 83 (3); p. 325-345.

[24] Bouley D, Fournel J, Leruth L. How do Treasury systems operate in Sub-Saharan Francophone Africa? OECD Journal on Budgeting; 2003, 2(4): p. 49-84.

[25] Matheson A, Kwon HS. Public sector modernization: A new agenda. OECD Journal on Budgeting. 2003, 3(1), p. 7-23.

[26] La Porta R, Lopez-de-Silanes F, Shleifer A, and Vishny R. The quality of government. Journal of Law, Economics, and Organization. 1999, 15: p. 222-279.

[27] Glennerster R, Shin Y. Does transparency pay? IMF Staff Papers. 2008, 55(1), p. 183-209.

[28] Alt, JE, Lassen DD. Fiscal transparency, political parties, and debt in OECD Countries. European Economic Review. 2006, 50; p. 1403-1439.

[29] Stein E, Talvi E, Grisanti A. Institutional arrangements and fiscal performance: The Latin American experience. National Bureau of Economic Research (NBER) Working Paper No. $6358 ; 1998$.

[30] Bastida F, and Benito B. Central government budget practices and transparency: An international comparison, Public Administration. 2007, 85(3), p. 667-716.

[31] Reinikka R, Svensson J. The power of information: Evidence from a newspaper campaign to reduce capture. Policy Research Working Paper. Washington DC: World Bank; 2004.

[32] Chortareas G, Stasavage D, Sterne G. Does it pay to be transparent? International evidence from central bank forecasts. The Federal Reserve Bank of St. Louis Review. 2002, (July/August), p. 99-118.

[33] Tanzi,V. International systems of public expenditure auditing: Lessons for Italy. In Nuovo. Sistema di Controlli Sulla Spesa Pubblica. Rome: Banca d'Italia; 1994.

[34] Siegle JT. Democratization and Economic Growth: the Contribution of Accountability Institutions. Ph.D Dissertation, School of Public Affairs, University of Maryland; 2001. 
[35] Gelos RG, Wei SJ. Transparency and international portfolio holdings. Journal of Finance. 2005, 60(6): p. 2987-3020.

[36] Matsumoto DR, and Juang L. Culture and Psychology. $3^{\text {rd }}$ Edition, Belmont, CA: Thomson and Wadsworth; 2004.

[37] Hofstede G. Culture and organizations. International Studies of Management and Organization. 1981, 10(4): p. 15-41.

[38] Kopelman RE, Brief AP, Guzzo RA. The role of climate and culture in productivity. In Schneider B, editor. Organizational Climate and Culture. San Francisco, CA: Jossey-Bass, 1990: p. 282-318

[39] House, R. J., N.S. Wright, and R.N. Aditya. Cross-cultural research on organizational leadership: A critical analysis and a proposed theory. In Earley PC, Erez M. editors. New Perspectives on International Industrial/Organizational Psychology. San Francisco, CA: Jossey-Bass; 1997: p. 535625.

[40] Hermann, M.G. Assessing leadership style: A trait analysis. Published in Post JM editor. The Psychological Assessment of Political Leaders Ann Arbor. The University of Michigan Press; 2003: p. 178-215

[41] Zaccaro SJ, Klimoski RJ. The nature of organizational leadership: An introduction. In Zaccaro SJ, Klimoski RJ, editors. The Nature of Organizational Leadership: Understanding the Performance Imperatives Confronting Today's Leaders. San Francisco, CA: Jossey-Bass; 2001, p. $3-41$.

[42] Ammeter AP, Douglas C., Gardner W.L, Hochwarter WA, Ferris GR. Towards a political theory of leadership. The Leadership Quarterly; 2002, 13(6); p. 751-796.

[43] Kurchner-Hawkins R, Miller R. Organizational politics: Building positive political strategies in turbulent times. In
Vigoda-Gadot E, Drory A, editors. Handbook of Organizational Politics: Organizational Politics Northampton, MA: Edward Elgar; 2006: p. 328-352.

[44] Lowe KB, Kroech KG, and Sivasubramaniam N. Effectiveness correlates of transformational and transactional leadership: A meta-analytic review of the MLQ literature. Leadership Quarterly; 1996,7(3): p. 385-425.

[45] Hoppe M. Culture and Leader Effectiveness: The GLOBE Study. Cited on June 15, 2015 from http://www.inspireimagi neinnovate.com/PDF/GLOBEsummary-by-Michael-H-Hopp e.pdf.

[46] Holloway JB. Leadership behavior and organizational climate: An empirical study in a non-profit organization. Emerging Leadership Journeys 2012 5(1): pp. 5-35.

[47] Northouse PG. Leadership: Theory and Practice. $5^{\text {th }}$ Ed. Thousand Oaks, CA Sage Publishing Co. 2010.

[48] Yuki G. Leadership in Organizations. $6^{\text {th }}$ ed. Upper Saddle, NJ: Prentice Press Hall, 2006.

[49] House RJ, Hanges PJ, Ruiz-Quintanilla SA, Dorfman PW, et al. Cultural influences on leadership and organizations: Project GLOBE. In Mobley WH, Gessner MJ, Arnold V. editors: Advances in Global Leadership 2nd edition. Bingley, UK: Emerald Group Publishing Ltd; 1999; p 171-233.

[50] Javidan M, Dorfman PW, Howell JP, Hanges PJ. Leadership and cultural context: A theoretical empirical examination based on Project GLOBE. In Nitin N, Rakesh K. editors: Handbook of Leadership Theory and Practices. Boston, Massachusetts: Harvard Business Press; 2010: p. 335-376.

[51] Lewin K., Lippit R, White RK. Patterns of aggressive behavior in experimentally-created social climates. Journal of Social Psychology; 1939:10,p. 271-301. 